\title{
Invited review: Fermented milk as antihypertensive functional food
}

\author{
L. M. Beltrán-Barrientos, A. Hernández-Mendoza, M. J. Torres-Llanez, A. F. González-Córdova, \\ and B. Vallejo-Córdoba ${ }^{1}$ \\ Laboratorio de Química y Biotecnología de Productos Lácteos, Coordinación de Tecnología de Alimentos de Origen Animal, Centro de \\ Investigación en Alimentación y Desarrollo, A.C. (CIAD), Carretera a La Victoria Km. 0.6, Apartado 1735, Hermosillo, Sonora, Mexico 83304
}

\begin{abstract}
Over the past decade, interest has risen in fermented dairy foods that promote health and could prevent diseases such as hypertension. This biological effect has mainly been attributed to bioactive peptides encrypted within dairy proteins that can be released during fermentation with specific lactic acid bacteria or during gastrointestinal digestion. The most studied bioactive peptides derived from dairy proteins are antihypertensive peptides; however, a need exists to review the different studies dealing with the evaluation of antihypertensive fermented milk before a health claim may be associated with the product. Thus, the objective of this overview was to present available information related to the evaluation of fermented milk containing antihypertensive peptides by in vitro and in vivo studies, which are required before a fermented functional dairy product may be introduced to the market. Although commercial fermented milks with antihypertensive effects exist, these are scarce and most are based on Lactobacillus helveticus. Thus, a great opportunity is available for the development of functional dairy products with new lactic acid bacteria that support heart health through blood pressure- and heart rate-lowering effects. Hence, the consumer may be willing to pay a premium for foods with important functional benefits.

Key words: hypertension, heart rate, antihypertensive peptides, in vitro studies, in vivo studies
\end{abstract}

\section{INTRODUCTION}

Interest has been increasing in certain foods, known as functional foods that, besides being traditionally nutritional, promote health or reduce diseases (Flambard and Johansen, 2007). Among these foods

Received July 2, 2015.

Accepted December 28, 2015.

${ }^{1}$ Corresponding author: vallejo@ciad.mx are dairy products, as they contain several bioactive compounds such as calcium, medium-chain fatty acids, CLA, lactose, and peptides (Ebringer et al., 2008). Milk proteins are a good source of bioactive peptides, which are latent or encrypted within the native protein, and some regions of their primary structure contain peptide sequences, considered strategic zones, that may exert different biological effects (Flambard and Johansen, 2007). However, because of their latency, they need to be released by proteolysis during gastrointestinal digestion or food processing, such as milk fermentation with lactic acid bacteria (LAB; Torres-Llanez et al., 2005; González-Cordova et al., 2011). Peptide bioavailability after oral administration plays a major role because it is crucial that they remain bioactive during digestion and absorption so that peptides can reach target organs and tissues through blood circulation (Vermeirssen et al., 2004). Milk bioactive peptides consist of 2 to $20 \mathrm{AA}$ residues that, besides being a valuable source of EAA, possess specific biological properties (Ricci-Cabello et al., 2012); some of these biological properties include mineral binding, antioxidant, antithrombotic, antimicrobial, opioid, and antihypertensive actions. These released peptides are present in fermented dairy products or are potential ingredients in health-promoting foods (Pihlanto et al., 2010; Ricci-Cabello et al., 2012).

Hypertension is a chronic degenerative disease characterized by values of blood pressure exceeding the normal range (Chobanian, 2003); it affects more than 1 billion people worldwide (WHO, 2011). Moreover, it is an important risk factor for developing other cardiovascular diseases, strokes, renal failure, cerebrovascular accidents, and many other complications (Bruce and Hanson, 2010). The renin-angiotensin system is the most important metabolic pathway in the control of blood pressure and vascular tone (Daien et al., 2012). The angiotensin-converting enzyme (ACE) plays a fundamental role in blood pressure, as it converts angiotensin I into angiotensin II, a potent vasoconstrictor; it also hydrolyzes the vasodilator peptides bradykinin and kallidin. The inhibition of ACE will cause a vaso- 
dilator response, which lowers blood pressure. Therefore, the pursuit for ACE-inhibitory substances, such as peptides, in food has been conducted so that such peptides could be used in the prevention and treatment of hypertension (Udenigwe and Mohan, 2014). Several ACE-inhibitory peptides have been identified in fermented milk and cheese (Pihlanto et al., 2010; Hernandez-Ledesma et al., 2011), although their actual antihypertensive mechanism is still unclear (Jäkälä and Vapaatalo, 2010). Although pharmacological therapies are the most widely used to treat hypertension, they have long-term secondary side effects. Fermented milk is recommended as a nonpharmacological treatment for hypertension, mainly because it lacks undesirable side effects (Flambard and Johansen, 2007); however, the European Food Safety Authority (EFSA) considers that the evidence is insufficient.

To date, antihypertensive peptides derived from milk proteins are the most studied, and several reviews addressing their production, bioavailability, and incorporation into foods have been published (Pihlanto and Korhonen, 2003; Korhonen and Pihlanto, 2006; Hernandez-Ledesma et al., 2011). However, a review of in vitro and in vivo studies dealing with the evaluation of antihypertensive peptides in fermented milk is needed. Thus, the objective of this overview was to present available information related to the evaluation of fermented milk containing antihypertensive peptides by in vitro and in vivo studies, which are required before a fermented functional dairy product can be introduced to the market.

\section{IN VITRO STUDIES}

The search for ACE-inhibitory peptides by in vitro studies is the most common strategy to select fermented milks with antihypertensive potential. Generally, the Cushman and Cheung (1971) spectrophotometric method is the most widely used technique for the evaluation of ACE-inhibitory activity. It uses hippuryl-HisLeu as a substrate, which is hydrolyzed by ACE to hippuric acid and His-Leu. However, ACE inhibitors ensure this reaction does not take place. This activity may be expressed as percentage of $\mathrm{ACE}$ inhibition (ACEI) or as the minimum concentration of protein to inhibit $50 \%$ of the enzymatic activity $\left(\mathbf{I C}_{50}\right.$; HernándezLedesma et al., 2011). Once, ACEI is tested and $\mathrm{IC}_{50}$ is determined in the water-soluble fraction of fermented milk, peptides may be determined by HPLC and mass spectrometry.

Most studies have screened different LAB for their capacity to exhibit high ACEI activity as a first step toward the development of antihypertensive fermented milk. Proteolysis by endogenous milk enzymes and enzymes from microbial cultures, such as LAB, has been shown to produce antihypertensive peptides during fermentation. The responsible bacterial enzymes are believed to be the cell wall proteinases, which break the protein into oligopeptides and use them for nutritional sources. The activity of cell wall proteinase, the proteolytic system, and activity of LAB are fundamental for the delivery of antihypertensive peptides (Flambard and Johansen, 2007). Thus, the specificity of the enzymes determines the sequence of the liberated peptides and is specific for each strain. Lactic acid bacteria in vitro screening for ACEI generally follows 2 approaches: the enzymatic characteristics of the bacterial cell wall proteinases and the properties of the strains to reduce ACE activity in vitro. The first approach was carried out in Lactobacillus helveticus, and it was reported that 3 specific cell wall proteinase patterns were correlated with ACEI in vitro (Flambard and Johansen, 2007).

Pihlanto et al. (2010) fermented milk with 25 different $\mathrm{LAB}$ and only 5 presented low $\mathrm{IC}_{50}$ in whey fractions: Leuconostoc mesenteroides 356 (0.44 mg/ $\mathrm{mL})$, Leuconostoc mesenteroides 358 (0.48 mg/mL), Lactococcus lactis ssp. lactis ATCC 19435 (0.5 mg/ $\mathrm{mL})$, Lactobacillus acidophilus ATCC $4356(0.42 \mathrm{mg} /$ $\mathrm{mL}$ ), and Lactobacillus jensenii ATCC 25258 (0.52 mg/ $\mathrm{mL}$ ). González-Córdova et al. (2011) fermented milk for $24 \mathrm{~h}$ with different Lactobacillus strains; Lactobacillus reuteri 14171, Lactobacillus fermentum ATCC 11976. and Lactobacillus johnsonii ATCC 33200 exhibited 42.04 to $83.36 \%$ ACEI activity, though $L b$. fermentum presented the lowest $\mathrm{IC}_{50}(21 \mathrm{mg} / \mathrm{mL})$ in whey fraction $<3 \mathrm{kDa}$. In a preliminary screening of 20 wild strains of Lc. lactis, those isolated from artisanal dairy products presented the highest ACEI activity and the lowest $\mathrm{IC}_{50}$ $(13-50 \mu \mathrm{g} / \mathrm{mL}$ ) in whey fractions $<3 \mathrm{kDa}$ (RodríguezFigueroa et al., 2010). Furthermore, fermented milk fractions obtained through reversed-phase HPLC of 2 Lc. lactis strains showed low $\mathrm{IC}_{50}$ for strains NRRL B-50571 $(0.034 \mu \mathrm{g} / \mathrm{mL})$ and NRRL B-50572 (0.041 $\mu \mathrm{g} /$ $\mathrm{mL}$; Rodríguez-Figueroa et al., 2012).

Another study evaluated ACEI activity in yogurt containing additional probiotic strains during refrigerated storage (Donkor et al., 2007). Yogurt was prepared using either a sole yogurt culture including Lactobacillus delbrueckii ssp. bulgaricus Lb1466 and Streptococcus thermophilus St1342, or with Lb. acidophilus L10, Lactobacillus casei L26, or Bifidobacterium lactis B94 besides the yogurt culture. All probiotic yogurts showed greater ACEI activity during the initial stage of storage (first $3 \mathrm{wk}$ ) versus the control; however, activity decreased afterward and $\mathrm{IC}_{50}$ ranged from 27.79 to $103.30 \mu \mathrm{g} / \mathrm{mL}$ in whey fractions (Donkor et al., 2007). Thus, studying 
ACEI stability during product shelf life is important in the development of functional fermented milk.

Fermented milks with Lactobacillus strains were the most studied for the screening of ACEI activity. Although Pihlanto et al. (2010) reported that fermented milk with specific Lactobacillus strains presented $\mathrm{IC}_{50}$ in the range of 0.42 to $0.52 \mathrm{mg} / \mathrm{mL}$, González-Córdova et al. (2011) reported a much higher $\mathrm{IC}_{50}$ range (21-146 $\mathrm{mg} / \mathrm{mL}$ ) for specific Lactobacillus. On the other hand, fermented milk with specific Lactococcus strains presented the lowest $\mathrm{IC}_{50}$ values $(13-50 \mu \mathrm{g} / \mathrm{mL}$; RodríguezFigueroa et al., 2010). From these reports, it is apparent that ACEI activity and $\mathrm{IC}_{50}$ are strain dependent rather than determined by the species.

In vitro studies are the first approach to find potential antihypertensive fermented milks; however, their effect in living organisms is required to establish a biological effect. The correlations between in vivo and in vitro systems are not apparent (Flambard and Johansen, 2007). Many of the strains inhibiting ACE activity in vitro do not reduce blood pressure in rats. The in vitro test mimics only the last interaction of the substrate with the ACE, whereas the in vivo system involves many other steps comprising many metabolic pathways following ingestion and gastrointestinal digestion (Flambard and Johansen, 2007). Hence, in vivo studies and clinical trials are necessary to demonstrate their physiological effect (Hernandez-Ledesma et al., 2011).

\section{IN VIVO STUDIES}

In vivo studies with spontaneously hypertensive rats (SHR) represent a useful animal model to evaluate the antihypertensive effect of fermented milk. Hypotensive effects have been demonstrated in SHR following oral administration of fermented milk (Table 1). Yamamoto et al. (1994) fermented milk with 16 different strains from 7 species of LAB commonly used in fermented dairy products and evaluated their antihypertensive effect in SHR. Fermented milk with Lb. helveticus had the most hypotensive effect. The systolic blood pressure (SBP) decreased significantly $(P<0.05)$ after a 4-h administration of $5 \mathrm{~mL} / \mathrm{kg}$ of $\mathrm{BW}$ of fermented milk containing Lb. helveticus CP790 $(-27.4 \pm 13.3$ $\mathrm{mmHg}), \mathrm{CP} 611(-20 \pm 9.6 \mathrm{mmHg}), \mathrm{CP} 615(-23 \pm$ $13.4 \mathrm{mmHg})$, or JCM1004 $(-29.3 \pm 13.6 \mathrm{mmHg})$. A strong decrease after $8 \mathrm{~h}$ of administration was also noted, and blood pressure returned to its initial value after $24 \mathrm{~h}$.

After the first findings of ACEI milk tripeptides Val-Pro-Pro (VPP) and Ile-Pro-Pro (IPP), several investigators have studied their antihypertensive effects. Nakamura et al. (1995a) were the first to isolate, identify, and evaluate these 2 ACEI peptides in in vitro and in vivo studies. Furthermore, Nakamura et al. (1995b) studied the antihypertensive effect of the tripeptides (IPP and VPP) and fermented milk with Lb. helveticus and Saccharomyces cerevisiae in SHR.

Table 1. In vivo studies with spontaneously hypertensive rats (SHR) ${ }^{1}$

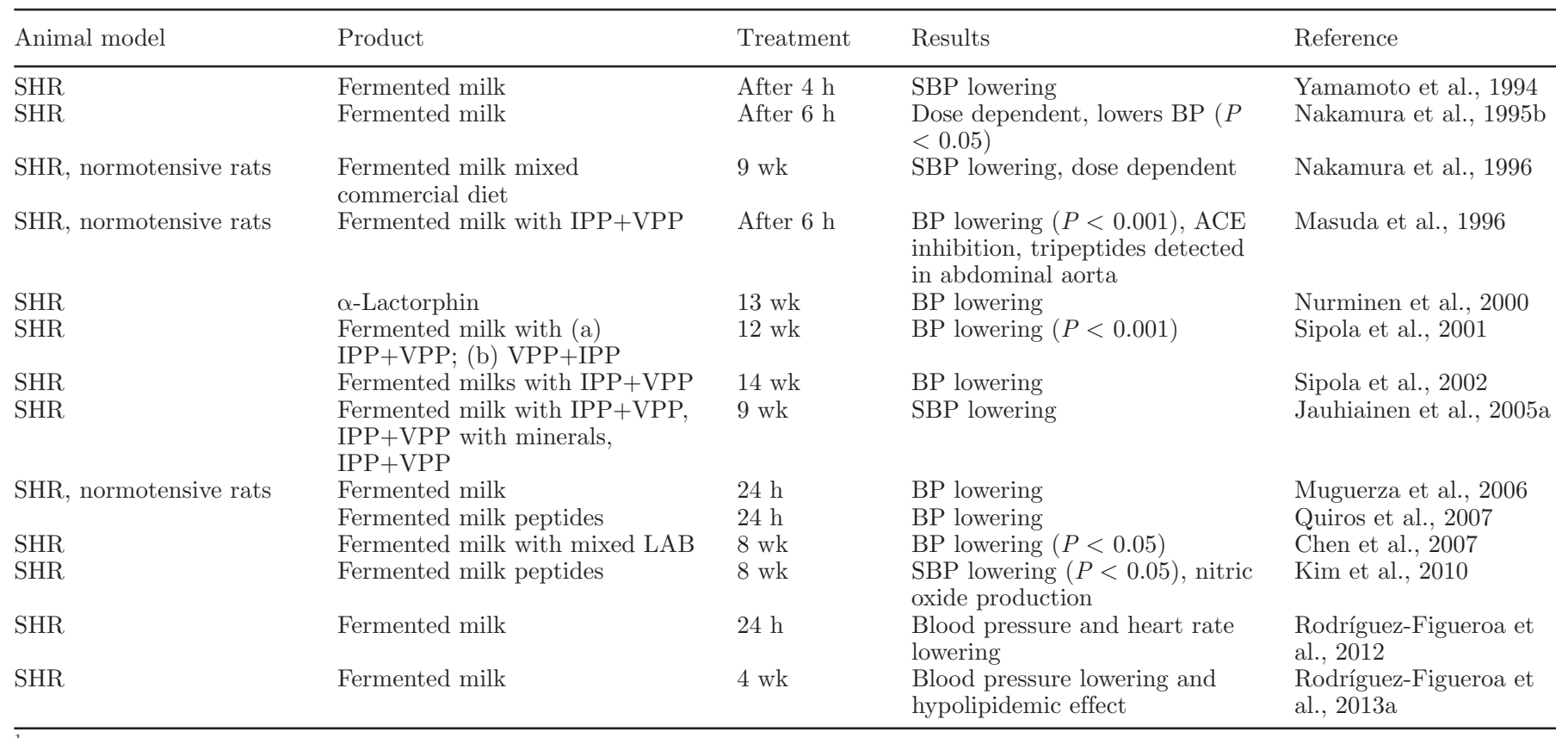

${ }^{1} \mathrm{BP}=$ blood pressure; $\mathrm{SBP}=$ systolic blood pressure; IPP $=$ isoleucine-proline-proline; $\mathrm{VPP}=$ valine-proline-proline; LAB $=$ lactic acid bacteria; $\mathrm{ACE}=$ angiotensin-converting enzyme. 
After a single oral administration of fermented milk $(5 \mathrm{~mL} / \mathrm{kg}$ of BW), SBP decreased significantly after 6 to $8 \mathrm{~h}$. The SBP of SHR that ingested the tripeptides also decreased after several hours. Moreover, all groups (IPP, VPP, and fermented milk) were significantly different from the control. Additionally, Nakamura et al. (1995b) administered fermented milk $(25 \mathrm{~mL} / \mathrm{kg}$ of $\mathrm{BW})$ or tripeptides $(10 \mathrm{mg} / \mathrm{kg}$ of BW) and SBP did not change in normotensive rats. They concluded that the hypotensive effect of tripeptides and fermented milk was specific to the hypertensive state (Nakamura et al., 1995b).

Another study by Nakamura et al. (1996) mixed lyophilized fermented milk $(0.25,1.25$, and $2.50 \%$ wt/ wt) containing $L b$. helveticus and Sac. cerevisiae with a standard commercial diet. The test group of SHR was fed with this mixed diet and for the control group they were fed with a standard commercial diet. The SBP of the control group increased during the course of the experiment to reach about $220 \mathrm{mmHg}$ at $17 \mathrm{wk}$. However, the SBP of the SHR test group tended to be lower - in a dose-dependent manner - than that of the control group when they were 13 wk old. Nakamura et al. (1996) concluded that the fermented milk not only had an antihypertensive effect after a single oral administration, but also had hypotensive effect following long-term feeding. Moreover, they analyzed ACE activity in different organs. They found a significant difference in ACE activity between aortas of the test group versus those of the control group and concluded that ACEI may be a possible mechanism of action (Nakamura et al. 1996).

Masuda et al. (1996) evaluated blood pressure, ACE activity, and the absorption of IPP and VPP in SHR and normotensive rats after $6 \mathrm{~h}$ of oral administration of $10 \mathrm{~mL} / \mathrm{kg}$ of BW fermented milk with $L b$. helveticus and Sac. cerevisiae containing these peptides or saline as control. In SHR on the fermented milk group, SBP decreased significantly $(26.4 \pm 3.1 \mathrm{mmHg} ; P<0.05)$, and it did not change in normotensive rats that were administered with fermented milk. The ACE activity was measured in abdominal aorta, lung, kidney, heart, and brain in SHR given fermented milk and was significantly lower $(P<0.05)$ than in the control group. Both IPP and VPP were detected in the abdominal aorta in SHR on the fermented milk group and not detected in the saline group; neither was detected in normotensive rats given fermented milk or saline. They concluded that these tripeptides were absorbed directly without being hydrolyzed by digestive enzymes, reached the abdominal aorta, inhibited ACE, and showed hypotensive effects in SHR (Masuda et al., 1996).

A study by Nurminen et al. (2000) investigated the antihypertensive effect of $\alpha$-lactorphin (a tetrapeptide:
Tyr-Gly-Leu-Phe) in SHR and normotensive rats. This peptide reduced blood pressure dose-dependently without affecting heart rate in normotensive and SHR. The greatest blood pressure reduction was with $100 \mu \mathrm{g} / \mathrm{kg}$ of BW in SHR, where SBP was reduced by $23.4 \mathrm{mmHg}$ and DBP was reduced by $17.4 \mathrm{mmHg}$. Although the involvement of the endogenous opioid system in cardiovascular regulation is not well understood, those authors concluded that this peptide possessed opioid-like activity in addition to helping modulate blood pressure (Nurminen et al., 2000).

Sipola et al. $(2001,2002)$ performed 2 long-term studies with SHR. In the first study, they evaluated the effect of treatments during the development of hypertension. They administered fermented milk with Lb. helveticus LBK16H enriched with VPP and IPP (fermented milk group), VPP and IPP dissolved in water (peptide group), and water (control group) to 6 -wk-old young prehypertensive SHR. Blood pressure increased gradually every week; at wk 10, it persisted in a stable hypertensive level in all groups. The fermented milk and peptide groups attenuated the development of hypertension in SHR compared with the control group $(P<0.01)$. By wk 12 in the treatment period, SBP was $12 \mathrm{mmHg}$ lower than in the control group. Moreover, the fermented milk group had a SBP $17 \mathrm{mmHg}$ lower than the control group. After a followup treatment, SBP from these 2 groups reached the same level as the control group. Sipola et al. (2001) concluded that long-term intake of fermented milk with tripeptides or IPP + VPP may help attenuate hypertension in SHR, and could be used as a nonpharmacological treatment for humans. In a second study, Sipola et al. (2002) evaluated the long-term effect of fermented milk products on the development of hypertension. They administered fermented milk with $L b$. helveticus LBK16H with tripeptides IPP + VPP (FM A), and the previously reported fermented milk with Lb. helveticus and Sac. cerevisiae (FM B; Nakamura et al., 1995a). Again, they observed that hypertension was significantly attenuated $(P<0.05)$ in the fermented milk groups FM A and FM B rather than in the control group (water) and skim milk group. By wk 14, SBP from the FM A was $10 \mathrm{mmHg}$ lower than the FM B and $21 \mathrm{mmHg}$ lower than the control group. This could be explained because the FM A had larger intake of tripeptides than the FM B group. They concluded that fermented milk with tripeptides helped to attenuate hypertension in SHR (Sipola et al., 2002). Moreover, these results confirm what was previously reported (Sipola et al., 2001) and reinforced that fermented milks containing these tripeptides (IPP + VPP) may be used for nonpharmacological prevention of hypertension. 
Jauhiainen et al. (2005a) evaluated the development of hypertension and the effects on arterial function in SHR. They administered different treatments to each group: (a) tap water, (b) minerals (potassium, calcium, magnesium, and sodium), (c) IPP + VPP and minerals, or (d) fermented milk Lb. helveticus, IPP + VPP, and minerals. After the intervention, the group provided with fermented milk with tripeptides and minerals attenuated hypertension more effectively than pure tripeptides or tripeptides with minerals. The water group had the highest SBP. Compared with the water group, the tripeptides and minerals group and the fermented milk with tripeptides and minerals groups presented a reduction in SBP of 12.7 and 16.9 $\mathrm{mmHg}$, respectively. Though the tripeptide and minerals group were also associated with the improvement of endothelium-dependent relaxation, the fermented milk group demonstrated a greater antihypertensive effect (Jauhiainen et al., 2005a). Though no significant differences were noted between groups $(P>0.05)$, those authors concluded that this fermented milk could be used as a functional food.

Muguerza et al. (2006) isolated different LAB from raw cow milk and evaluated the ACEI activity of fermented milk with these LAB. Later, they fermented milk with 4 selected strains with different strains of Enterococcus faecalis (which had the most ACEI activity), obtained the whey fraction, and evaluated the antihypertensive effect in SHR and normotensive rats after a single oral administration. Those SHR treated with water and unfermented milk (controls) had similar blood pressure values (SBP and diastolic blood pressure, DBP) throughout the whole experiment. Systolic blood pressure and DBP from SHR treated with Captopril (50 mg/kg of BW; Sigma-Aldrich, St. Louis, MO) had their maximal decrease $6 \mathrm{~h}$ after administration. As for the fermented milks, their maximal decreases were observed $4 \mathrm{~h}$ after administration. Diastolic blood pressure were similar to those of the Captopril group; however, SBP reduction was less pronounced compared with Captopril. Furthermore, no differences $(P>0.05)$ were noted in blood pressure of normotensive rats treated with any of the interventions, which suggests that the effect of fermented milk with these LAB is specific to the hypertensive state. Those authors concluded that raw bovine milk is a good source of LAB, which can be used as starter cultures with potential applications for the dairy industry in the generation of novel products with an added health value, such as antihypertensive activity (Muguerza et al., 2006).

Quiros et al. (2007) isolated and identified the peptides responsible for the effect of fermented milk with different strains of Enterococcus faecalis reported by Muguerza et al. (2006). They conducted in vitro and in vivo studies with SHR administered with peptides identified in fermented milk. Water was used as a negative control because blood pressure did not change throughout the experiment. Captopril $(50 \mathrm{mg} / \mathrm{kg})$ was used as the positive control, as it decreased blood pressure after 4 to $6 \mathrm{~h}$ after administration. After a 4 -h administration of peptide $\beta$-CN f(133-138) LHLPLP $(2 \mathrm{mg} / \mathrm{kg}$ ), blood pressure also decreased significantly $(P<0.05)$, though it was less pronounced than with Captopril. Nevertheless, after a 2-h administration of this peptide, DBP in SHR decreased even more than Captopril group. Furthermore, $6 \mathrm{mg} / \mathrm{kg}$ of the peptide $\beta-C N \quad f(58-76)$ LVYPFPGPIPNSLPQNIPP caused a significant $(P<0.05)$ maximum decrease on blood pressure at $6 \mathrm{~h}$ after administration. They concluded that the administration of LHLPLP at 2, 4, and $6 \mathrm{~h}$ post-administration decreased SBP and DBP even more than IPP and VPP, as previously reported (Nakamura et al., 1995a,b).

A study by Chen et al. (2007) evaluated whether the combination of milk fermentation by LAB ( $L b$. casei, Lb. acidophilus, Strep. thermophilus, Lb. bulgaricus, and Bifidobacterium) and proteolysis with Prozyme 6 (Amano Pharmaceutical Co., Nagoya, Japan) might accelerate the production of antihypertensive peptides from traditional dairy products. Chen et al. (2007) evaluated the antihypertensive effect of fermented milk whey fraction on SHR during the development of hypertension. In the first $2 \mathrm{wk}$, no significant differences $(P>0.05)$ were observed among the SHR in fermented milk and the control. However, by the fourth week, SBP of the SHR in the fermented milk group was significantly $(P<0.05)$ lower than that of the control group. By wk 8 , the SBP and DBP were 22 and 21.5 $\mathrm{mmHg}$ lower $(P<0.05)$ than those from the control group, respectively. This effect was mainly attributed to tripeptides Gly-Thr-Trp and Gly-Val-Trp. Hence, this fermented milk whey may be used as a functional ingredient for the prevention of hypertension.

Kim et al. (2010) evaluated aortic thickness and whether the administration of fermented milk produced with $L b$. helveticus and Sac. cerevisiae to SHR lowered blood pressure by modulating ACE activity or producing NO. For the control groups, one group was administered skim milk and the other group was administered Captopril. Whereas the SBP of the Captopril group was modulated throughout the intervention, the fermented milk group had significantly $(P<0.05)$ suppressed SBP compared with the skim milk group. The Captopril and fermented milk groups showed ACEI activity in serum and abdominal aorta tissue extract, which was significantly higher than that in the skim milk group $(P<0.05)$. Moreover, plasma NO concentration was significantly higher in the fermented milk 
and Captopril groups than in the skim milk group $(P$ $<0.05$ ). Similarly, the mean aortic thickness was significantly less in the fermented milk and the Captopril groups than in the skim milk group $(P<0.05)$. Thus, Kim et al. (2010) concluded that peptides in fermented milk not only inhibit ACE activity, but also produce the vasodilator $\mathrm{NO}$, which attenuates hypertension in SHR (Kim et al., 2010). It is known that NO produced and released in the endothelium is considered a main vasodilator; thus, the impairment of its production in SHR precedes the development of hypertension (Cruzado et al., 2002).

Rodríguez-Figueroa et al. (2013b) administered a single dose (35 or $50 \mathrm{mg} / \mathrm{kg}$ of BW) of fermented milk with Lc. lactis strains NRRLB-50571 or NRRLB-50572 to SHR. Blood pressure was measured at 2, 4, 6, and $24 \mathrm{~h}$ after administration. Maximal reductions of SBP and DBP were observed at $6 \mathrm{~h}$ after administration from Captopril (40 mg/kg of BW). However, fermented milk with NRRL-B50571 (35 mg/ $\mathrm{kg}$ of BW) or NRRL-B50572 (50 mg/kg of BW) also had maximal reductions at $6 \mathrm{~h}$ after administration. Furthermore, $24 \mathrm{~h}$ after single oral administration, SBP in SHR on fermented milk with NRRL-B50572 (50 mg/kg of BW) was not significantly different from those on Captopril $(P>0.05)$. Because heart rate reduction may be an important strategy for the treatment of a wide range of cardiac disorders, those authors evaluated not only the antihypertensive effect of these fermented milks, but also the heart rate-lowering effect. Heart rate was also decreased after $24 \mathrm{~h}$ of fermented milk administration.

Another study by Rodríguez-Figueroa et al. (2013a) evaluated the antihypertensive and hypolipidemic effect in SHR of fermented milk with Lc. lactis (NRRLB50571 or NRRL-B50572) administered ad libitum after a long-term administration (4 wk). Fermented milk reduced blood pressure and its maximal effect was recorded by the second and third week with NRRLB50571 fermented milk, which was not significantly different from Captopril $(P>0.05)$. Furthermore, fermented milk also had a hypolipidemic effect. However, clinical studies are necessary to evaluate their effect in humans.

Initially, most in vivo studies with SHR were performed with milk fermented with Lb. helveticus in a single dose (Yamamoto et al., 1994; Nakamura et al., 1995b, 1996; Masuda et al., 1996) and after long-term administration (Sipola et al., 2001, 2002; Jauhiainen et al., 2005a). Those authors attributed the antihypertensive effect to the ACEI tripeptides IPP and VPP. However, other possible mechanisms for these tripeptides beyond ACEI may exist (Jäkälä et al., 2010; Kim et al., 2010). Other in vivo studies with SHR were carried out by administering fermented milk with wild strains of $E$. faecalis in a single dose (Muguerza et al., 2006). In recent years, authors explored the antihypertensive effect on SHR of fermented milk with wild strains of Lc. lactis in a single dose (Rodríguez-Figueroa et al., 2013b) and after long-term administration (Rodríguez-Figueroa et al., 2013a). These fermented milks contained ACEI peptides other than IPP and VPP (Quiros et al., 2007; Rodríguez-Figueroa et al., 2012).

Although most authors attribute the hypotensive effect of fermented milk to ACEI peptides, other possible antihypertensive mechanisms may be involved (Kim et al., 2010; Marques et al., 2012; Udenigwe and Mohan, 2014; Majumder and Wu, 2015). Hence, it is necessary to carry out in vivo studies with SHR for evaluating these other possible mechanisms. Detailed knowledge of peptide structural requirements for antihypertensive activity and the mechanisms involved beyond ACEI will allow for the design of functional fermented milk with a blood pressure-lowering effect.

\section{CLINICAL STUDIES}

Several studies have been performed in humans (Table 2), where the principal objective is to ensure a hypotensive effect of these fermented milks. These are randomized controlled clinical trials, which have a test group versus a control (placebo) group. Milk fermented by $L b$. helveticus and Sac. cerevisiae is the most widely studied for its antihypertensive effect (Hata et al., 1996; Kajimoto et al., 2002; Hirata et al., 2002; Seppo et al., 2002, 2003; Nakamura et al., 2004; Mizushima et al., 2004; Jauhiainen et al., 2005b).

Hata et al. (1996) provided $95 \mathrm{~mL} / \mathrm{d}$ of fermented milk with Lb. helveticus and Sac. cerevisiae with tripeptides (1.1 mg of IPP $+1.5 \mathrm{mg}$ of VPP) to the test group and $95 \mathrm{~mL} / \mathrm{d}$ of acidified milk to the control group in a study of 30 hypertensive subjects treated with hypotensive medication. In the test group, a significant $(P$ $<0.05)$ decrease was noted in wk $4(9.4 \pm 3.6 \mathrm{mmHg})$ and $8(14.1 \pm 3.1 \mathrm{mmHg})$ for SBP; however, for DBP, a decrease of $6.9 \pm 2.2 \mathrm{mmHg}$ was observed until wk 8 of ingestion. In the placebo group, SBP and DBP did not decrease significantly $(P>0.05)$ during treatment. Although subjects were treated with antihypertensive medication, a greater decrease of blood pressure was noted in the test group versus the control group. The authors concluded that daily consumption of the product for at least 8 wk was required for a reduction in blood pressure (Hata et al., 1996). Their study had several limitations. First, the groups' clinical characteristics (weight and body mass index) were significantly different, resulting in heterogeneous groups. This was a problem because random assignment should ensure homogeneous or comparable groups. Randomization dis- 
Table 2. Clinical trials with antihypertensive fermented milks

\begin{tabular}{|c|c|c|c|c|c|c|c|}
\hline $\begin{array}{l}\text { Subject } \\
\text { (n) }\end{array}$ & Hypertension & $\begin{array}{l}\text { Test product: } \\
\text { Fermented milk }\end{array}$ & Dose test product & Control product & $\begin{array}{l}\text { Treatment } \\
(\mathrm{wk})\end{array}$ & $\begin{array}{l}\text { Results: } \Delta \text { test } \\
\text { group vs. control group }{ }^{1}\end{array}$ & Reference \\
\hline 30 & $\begin{array}{l}\text { Hypertension stage } 1 ; \\
\text { hypotensive medication }\end{array}$ & $\begin{array}{l}\text { Lactobacillus helveticus } \\
\text { and Saccharomyces } \\
\text { cerevisiae }\end{array}$ & $\begin{array}{l}95 \mathrm{~mL} / \mathrm{d}(1.1 \mathrm{mg} \text { of } \\
\mathrm{IPP}+1.5 \mathrm{mg} \text { of } \mathrm{VPP})\end{array}$ & Acidified milk & 8 & $\begin{array}{l}-9.7 \pm 3.35 \mathrm{mmHg} \mathrm{SBP}^{* *} \\
-4.4 \pm 2.2 \mathrm{mmHg} \mathrm{DBP}^{*}\end{array}$ & $\begin{array}{l}\text { Hata et al., } \\
1996\end{array}$ \\
\hline 64 & $\begin{array}{l}\text { Hypertension stage } 1 \text {; no } \\
\text { hypotensive medication }\end{array}$ & $\begin{array}{l}\text { Lb. helveticus and } \\
\text { Sac. cerevisiae; Lb. } \\
\text { helveticus } \text { CM } 4\end{array}$ & $\begin{array}{l}150 \mathrm{~mL}, \text { twice per day } \\
(1.12 \mathrm{mg} \text { of IPP }+ \\
0.79 \mathrm{mg} \text { of VPP })\end{array}$ & $\begin{array}{l}\text { Fermented milk } \\
\text { with Lb. bulgaricus } \\
\text { and Streptococcus } \\
\text { thermophilus }\end{array}$ & 8 & $\begin{array}{l}-13 \pm 10.55 \mathrm{mmHg} \mathrm{SBP}^{* *} \\
-8.4 \pm 7.45 \mathrm{mmHg} \mathrm{DBP}^{* *}\end{array}$ & $\begin{array}{l}\text { Kajimoto et } \\
\text { al., } 2002\end{array}$ \\
\hline 32 & $\begin{array}{l}\text { Hypertension stage } 1 \\
\text { and } 2 ; \text { no hypotensive } \\
\text { medication }\end{array}$ & $\begin{array}{l}\text { Lb. helveticus and } \\
\text { Sac. cerevisiae; Lb. } \\
\text { helveticus CM4 }\end{array}$ & $\begin{array}{l}120 \mathrm{~mL} / \mathrm{d}(1.6 \mathrm{mg} \text { of } \\
\mathrm{IPP}+2.66 \mathrm{mg} \mathrm{VPP})\end{array}$ & Acidified milk & 8 & $\begin{array}{l}-12.1 \pm 10.2 \mathrm{mmHg} \mathrm{SBP}^{*} \\
-5.8 \pm 9.6 \mathrm{mmHg} \mathrm{DBP}^{*}\end{array}$ & $\begin{array}{l}\text { Hirata et al., } \\
2002\end{array}$ \\
\hline 39 & $\begin{array}{l}\text { Hypertension stage } 1 ; \\
\text { hypotensive medication }\end{array}$ & Lb. helveticus & $\begin{array}{l}150 \mathrm{~mL} / \mathrm{d}(2.25 \mathrm{mg} \text { of } \\
\mathrm{IPP}+3 \mathrm{mg} \text { of VPP })\end{array}$ & $\begin{array}{l}\text { Fermented milk } \\
\text { with Lactococcus } \\
\text { spp. }\end{array}$ & 21 & $\begin{array}{l}-6.7 \pm 2.55 \mathrm{mmHg} \mathrm{SBP}^{*} \\
-3.6 \pm 1.45 \mathrm{mmHg} \mathrm{DBP}\end{array}$ & $\begin{array}{l}\text { Seppo et al., } \\
2003\end{array}$ \\
\hline 106 & $\begin{array}{l}\text { Prehypertension; no } \\
\text { hypotensive medication }\end{array}$ & $\begin{array}{l}\text { Lb. helveticus and } \\
\text { Sac. cerevisiae; } L b . \\
\text { helveticus } \text { CM } 4\end{array}$ & $\begin{array}{l}2 \times 150 \mathrm{~mL} / \mathrm{d}(1.13 \\
\mathrm{mg} \text { of IPP }+0.74 \mathrm{mg} \\
\text { of VPP })\end{array}$ & Skim milk & 12 & $\begin{array}{l}-6.1 \pm 7.05 \mathrm{mmHg} \mathrm{SBP}^{* *} \\
-3.8 \pm 6.75 \mathrm{mmHg} \mathrm{DBP}^{* *}\end{array}$ & $\begin{array}{l}\text { Nakamura et } \\
\text { al., } 2004\end{array}$ \\
\hline 46 & $\begin{array}{l}\text { Prehypertension no } \\
\text { hypotensive medication }\end{array}$ & $\begin{array}{l}\text { Lb. helveticus and Sac. } \\
\text { cerevisiae }\end{array}$ & $\begin{array}{l}160 \mathrm{~g} / \mathrm{d}(1.2 \mathrm{mg} \text { of } \\
\mathrm{IPP}+2.0 \mathrm{mg} \text { of VPP })\end{array}$ & Acidified milk & 4 & $\begin{array}{l}-1.5 \pm 8.55 \mathrm{mmHg} \mathrm{SBP}^{*} \\
-1.7 \pm 8.85 \mathrm{mmHg} \mathrm{DBP}\end{array}$ & $\begin{array}{l}\text { Mizushima et } \\
\text { al., } 2004\end{array}$ \\
\hline 94 & $\begin{array}{l}\text { Hypertension stage } 1 ; \text { no } \\
\text { hypotensive medication }\end{array}$ & Lb. helveticus & $\begin{array}{l}2 \times 150 \mathrm{~mL} / \mathrm{d}(11.25 \\
\mathrm{mg} \text { of IPP }+15 \mathrm{mg} \text { of } \\
\mathrm{VPP})\end{array}$ & $\begin{array}{l}\text { Fermented milk } \\
\text { with Lactococcus } \\
\text { spp. }\end{array}$ & 10 & $\begin{array}{l}-4.1 \pm 6.6 \mathrm{mmHg} \text { SBP } \\
-1.8 \pm 3.7 \mathrm{mmHg} \mathrm{DBP}\end{array}$ & $\begin{array}{l}\text { Jauhiainen et } \\
\text { al., 2005b }\end{array}$ \\
\hline
\end{tabular}

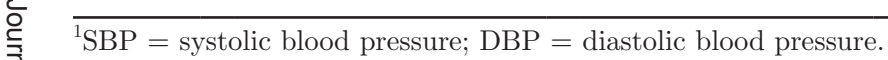

spp.

${ }^{*} P<0.05 ;{ }^{* *} P<0.01$ 
tributes individual differences equally across the groups so that the groups systematically differ only in the way that they have been treated (Armijo-Olivo et al., 2009). Another limitation was that subjects who did not show good adherence were excluded from the analysis, instead of doing intention-to-treat analysis (ITT). An ITT analysis includes every subject who is randomized according to randomized treatment assignment. It ignores noncompliance, protocol deviations, withdrawal, and anything that happens after randomization. The ITT analysis is described as once randomized, always analyzed (Gupta, 2011).

In another randomized, double blinded, placebo-controlled study with hypertensive subjects (without hypotensive medication; Kajimoto et al., 2002), test and control groups ingested $150 \mathrm{~mL}$ of the product twice a day (morning and evening). Subjects were administered fermented milk with Lb. helveticus and Sac. cerevisiae and fermented milk by Lb. helveticus CM4 mixture with $(1.12 \mathrm{mg}$ of $\mathrm{VPP}+0.79 \mathrm{mg}$ of IPP) as the test group. The control group ingested milk fermented with Lb. bulgaricus and Strep. thermophilus as placebo. In the test group, SBP and DBP decreased significantly $(P<0.01)$ by the first week compared with control group. By wk 8, SBP decreased by $13.9 \pm 11.4 \mathrm{mmHg}$ and DBP decreased by $9.1 \pm 7.5 \mathrm{mmHg}$ compared with the control group. Moreover, after the treatment ended, blood pressure from the test group returned to its initial value (Kajimoto et al., 2002). In their study, it was not reported if groups resulting from randomization were homogeneous and statistically equal. Also, the placebo drink was fermented milk, which could have itself provided antihypertensive bioactive peptides.

Hirata et al. (2002) performed an 8-wk double blind controlled trial with untreated subjects with mild or moderate hypertension (140-180 $\mathrm{mmHg} \mathrm{SBP}$ and 90$105 \mathrm{mmHg}$ DBP). The test product was prepared with a mixture of fermented milk with $L b$. helveticus and Sac. cerevisiae, and $L b$. helveticus CM4 with $1.6 \mathrm{mg}$ of IPP $+2.66 \mathrm{mg}$ of VPP. The control product was artificially acidified milk as placebo. Both groups ingested $120 \mathrm{~mL}$ of the product. After the 8-wk intervention, SBP of the test group decreased by $14.5 \pm 9.9$ compared with the baseline, with a significant $(P<0.05)$ difference of 12.1 \pm 10.2 between the test group and the control group. In DBP, a significant decrease of $8.1 \pm 10 \mathrm{mmHg}$ from the baseline was noted in the test group, though no significant difference was observed in the control group. Given the effectiveness of the fermented milk product, Hirata et al. (2002) concluded that it could be used for hypertension management. However, they did not mention whether group allocation was carried out through randomization. Additionally, it was not reported if ITT analysis was used.
Seppo et al. (2002) administered $150 \mathrm{~mL}$ of fermented milk with $L b$. helveticus LBK16H with tripeptides (IPP and VPP) once a day to the study group. In this short-term study (8 wk), SBP and DBP decreased significantly $(P<0.05)$ compared with the control group. Although blood pressure was lower in the test group than in the control group, this study could not be considered as a preliminary one because the number of participants was relatively small (17 volunteers). Later, Seppo et al. (2003) carried out a long-term study (21 wk) with hypertensive subjects who were taking hypotensive medication. The test group was administered with fermented milk with $L b$. helveticus LBK16H with tripeptides (IPP and VPP) and the control group with fermented milk with Lactococcus spp. The SBP decreased significantly $(P<0.05)$ in comparison to the control group $(6.7 \pm 3 \mathrm{mmHg})$, although there was no significant difference between groups in DBP $(P>0.05$; Seppo et al., 2003). That study also used fermented milk with Lactococcus spp. as the placebo, which could have led to the production of bioactive antihypertensive peptides. Hence, this could explain why their study did not report significant differences between the treatment and placebo groups. Furthermore, it was not specified which pharmacological antihypertensive medications were used by the subjects. Also, in this study ITT analysis was not reported.

In a placebo-controlled, double blind study of 12wk intervention, Nakamura et al. (2004) administered $150 \mathrm{~mL}$ twice a day of a mixture of fermented milk with $L b$. helveticus and Sac. cerevisiae $+L b$. helveticus CM4-fermented milk + fermented milk with $L b$. delbrueckii ssp. bulgaricus and Strep. thermophilus to the test group. The control group received skim milk as placebo. By the wk 12 intervention, SBP from the test group decreased significantly by $6.1 \pm 5.7 \mathrm{mmHg}(P<$ 0.05 ) from its initial value and was significant different from the control group $(P<0.05)$. Moreover, the test group DBP was reduced by $3.8 \pm 6.3 \mathrm{mmHg}$ by wk $12(P<0.05)$. Although a small reduction in blood pressure was noted, the sample size was big enough to give enough statistical power to detect significant differences between groups (Nakamura et al., 2004).

Mizushima et al. (2004) performed a 4-wk clinical trial with hypertensive men $(\geq 130 / 85 \mathrm{mmHg}$ blood pressure) with no history of antihypertensive drugs. The supplementary drink for the test group was prepared as previously reported by Nakamura et al. (2004), where skim milk was fermented with $L b$. helveticus and Sac. cerevisiae. The control drink was artificially acidified skim milk as a placebo. Both study groups ingested $160 \mathrm{~mL}$ of their respective product. By wk 2, SBP in the test group decreased by $4.3 \pm 8.5$ and DBP by $1.7 \pm 9.9 \mathrm{mmHg}$; by wk 4 , SBP decreased by $5.2 \pm$ 
$8.1 \mathrm{mmHg}$ and DBP decreased by $2.0 \pm 8.6 \mathrm{mmHg}$, values that were significantly $(P<0.05)$ different from the baseline. Although the test group had a greater decrease in blood pressure than the placebo group, it was not significantly $(P>0.05)$ different. This might be because the sample size was not large enough to give enough statistical power to detect the difference (Mizushima et al., 2004). In their study, ITT analysis was not reported.

A randomized, double blind, controlled clinical study of $10 \mathrm{wk}$ was performed by Jauhiainen et al. (2005b). The test group was administered twice a day with 150 $\mathrm{mL}$ of fermented milk with $L b$. helveticus LBK16H with tripeptides (IPP + VPP). The control group received $150 \mathrm{~mL}$ of fermented milk with Lactococcus spp. twice a day. This study differed from other clinical trials because they used a 24-h ambulatory blood pressure measurement, which is a reliable method that avoids the "white coat hypertension" effect. The SBP of the test group decreased by $4.7 \pm 10 \mathrm{mmHg}$ and DBP decreased by $2.7 \pm 8 \mathrm{mmHg}$ by wk 10 . Systolic blood pressure was significantly $(P<0.05)$ different from that at baseline, but it was not different from the control group $(P>0.05)$. In their study, the control group, which was fermented milk, could have provided antihypertensive peptides.

Most clinical trials were carried out with $L b$. helveticus and Sac. cerevisiae fermented milk with tripeptides IPP and VPP. However, most recently the antihypertensive effect of fermented milk with Lc. lactis NRRLB-50571 was evaluated in hypertensive subjects in a randomized controlled clinical study (Beltran-Barrientos, 2013). Fermented milk was prepared as previously reported by Rodríguez-Figueroa et al. (2010, 2012, 2013a). The test group received $150 \mathrm{~mL}$ of fermented milk and the control group received $150 \mathrm{~mL}$ of acidified milk as placebo. By the end of the 8-wk intervention, SBP decreased by $13 \pm 12.4 \mathrm{mmHg}$ and was significantly $(P<0.05)$ different from control group. Although a small reduction in DBP was noted, the sample size was not large enough to give sufficient statistical power to detect significant differences between groups (Beltran-Barrientos, 2013).

Although the antihypertensive effect of the tripeptides IPP and VPP has been reported in multiple clinical trials, the EFSA (2011) published an opinion of the Panel on Dietetic Products, Nutrition, and Allergies in the scientific substantiation of a health claim related to IPP and VPP and the maintenance of normal blood pressure. The EFSA (2011) identified 20 published intervention studies, some of which were adequately powered to detect small differences between groups in SBP, though there were no differences in DBP. Other studies displayed major methodological limitations, such as randomization, treatment allocation, blinding, and statistical analysis. The panel concluded that a cause and effect on the consumption of IPP and VPP and the maintenance of normal blood pressure has not been established (EFSA 2011). Furthermore, in a metaanalysis of 19 human clinical trials, the efficacy of the tripeptides IPP and VPP for lowering blood pressure in prehypertensive or mildly hypertensive subjects was demonstrated; however, antihypertensive effects were not observed in all individual studies (Turpeinen et al., 2013).

According to Jäkälä and Vapaatalo (2010), the problem in the functional food research is that differences in human studies are usually quite small between the active and placebo treatment, so the study population needs to be very large to prove the efficacy conclusively. Jäkälä and Vapaatalo (2010) suggested that more emphasis should be given to preclinical studies, providing that results are consistent and effects are shown repeatedly and by several research groups. Also, with sound hypotheses and well-defined methods, these studies can give valuable information. Thus, it appears that, for the time being, antihypertensive lactotripeptide-containing milk products do not have approved health claims in the European Union (Jäkälä and Vapaatalo, 2010).

In some countries, government regulations have set requirements for health claims on functional foods, which includes, among other requirements, evidence of physiological effects in human subjects. Consequently, verifying health claims and commercialization of functional products require substantial research investment. Furthermore, obtaining health claims in countries where regulations exist remains a challenging process that may hinder commercialization of functional food products (Udenigwe, 2014).

\section{ANTIHYPERTENSIVE FERMENTED MILK AS A FUNCTIONAL FOOD}

As hypertension continues to increase worldwide, the search for and production of antihypertensive functional foods has increased. Several fermented milk products are on the market, including Ameal (Calpis Co., Tokyo, Japan), Calpis (Calpis Co.), and Evolus (Valio, Helsinki, Finland), among others (Table 3). Although these products attribute their antihypertensive effect to the bioactive peptides present in the fermented milk, they also contain minerals such as potassium and calcium, which have been demonstrated to have a positive effect on blood pressure (Phelan and Kerins, 2011; Ricci-Cabello et al., 2012).

Scientifically proven health claims and acquisition of exclusivity rights of using novel food ingredients in functional food products has been observed as a critical factor in the ultimate success of these food products in 
Table 3. Commercial antihypertensive fermented milks ${ }^{1}$

\begin{tabular}{|c|c|c|c|}
\hline Brand name & Manufacturer & Description of product & $\begin{array}{l}\text { Peptide } \\
\text { sequence }\end{array}$ \\
\hline Ameal S & $\begin{array}{l}\text { Calpis Co. (Tokyo, } \\
\text { Japan) }\end{array}$ & $\begin{array}{l}\text { Fermented skim milk by Lactobacillus helveticus and Saccharomyces cerevisiae, } \\
\text { contains angiotensin converting enzyme inhibitory tripeptides }\end{array}$ & $\begin{array}{l}\text { Val-Pro-Pro } \\
\text { Ile-Pro-Pro }\end{array}$ \\
\hline Danaten $^{2}$ & $\begin{array}{l}\text { Danone (Paris, } \\
\text { France) }\end{array}$ & $\begin{array}{l}\text { Fermented milk by Lb. helveticus DN-119 905, contains angiotensin converting } \\
\text { enzyme inhibitory tripeptides }\end{array}$ & $\mathrm{ND}^{3}$ \\
\hline
\end{tabular}

${ }^{1}$ Adapted from Ricci-Cabello et al., 2012.

${ }^{2}$ No longer available.

${ }^{3} \mathrm{ND}=$ not described.

the market (Khan et al., 2013). Indeed, several of these commercial products carry intellectual property rights. The technology surrounding Lb. helveticus Cardi-04 (Chr. Hansen, Hørsholm, Denmark) is protected by several patent applications. These include the use of LAB to prepare antihypertensive peptides and functional foods containing these [WO 2003/082019 A3 (Flambard, 2003) and WO 2004/015125 A1 (Flambard, 2004a)], as well as fermented food products containing bioactive compounds that reduce the heart rate (WO 2004/089097 A1; Flambard, 2004b; Flambard and Johansen, 2007). Recently, the technology using Lc. lactis (NRRL-B50571) for the production of fermented milk with antihypertensive peptides was protected by a US patent (US 8,865,155; Vallejo Galland et al., 2014).

\section{CONCLUSIONS AND FUTURE TRENDS}

Hypertension is a disease that affects not only adults, but also children worldwide. Although antihypertensive drugs play a fundamental role in blood pressure regulation, they can present several side effects; therefore, a number of studies have searched for food substances that can help reduce or prevent hypertension. Some fermented milks have been demonstrated in vitro, in vivo, and in clinical trials to be antihypertensive agents, and their effects in most cases have been attributed to milk peptides. These fermented milks are as effective as synthetic ACEI; therefore, they can be considered as hypotensive agents because they can form part of the daily diet. Although a great deal of research related to antihypertensive peptides has been done, there is a need to find and evaluate new LAB that possess the ability to generate this bioactivity as well as good technological properties for the production of fermented dairy products. As commercial fermented milks with antihypertensive effects are scarce and most are based on $L b$. helveticus, a great opportunity exists for the development of fermented functional dairy products with the use of specific new LAB. These studies may include LAB screening for ACEI, in vivo studies with SHR, and clinical trials to test the efficacy of the fermented milk product. Before conducting clinical trials, it is extremely important to have properly designed randomized, controlled, double-blind studies to avoid methodological limitations and an adequate sample size to give enough power to detect differences between groups. It is also important to develop the regulatory legislation that allows the introduction of health claims for functional dairy foods, especially in countries where this subject is underdeveloped. Finally, the development of functional foods that support a healthy heart through lowering blood pressure offers new market opportunities.

\section{ACKNOWLEDGMENTS}

The authors thank the National Council for Science and Technology (CONACyT; Mexico City) of Mexico for the graduate scholarship for author Beltrán-Barrientos and the research grant CB-2014-01 (230338).

\section{REFERENCES}

Armijo-Olivo, S., S. Warren, and D. Magee. 2009. Intention to treat analysis, compliance, drop-outs and how to deal with missing data in clinical research: A review. Phys. Ther. Rev. 14:36-49.

Beltran-Barrientos, L. M. 2013. Estudio clínico controlado aleatorizado del efecto antihipertensivo asociado al consumo de leche fermentada. MS Thesis. Centro de Investigacion en Alimentacion y Desarrollo, A.C. Mexico.

Bruce, K. D., and M. Hanson. 2010. The development origins, mechanisms, and implications of metabolic syndrome. J. Nutr. 140:648652. http://dx.doi.org/10.3945/jn.109.111179.

Chen, G. W., J. S. Tsai, and B. Sun Pan. 2007. Purification of angiotensin I-converting enzyme inhibitory peptides and antihypertensive effect of milk produced by protease-facilitated lactic fermentation. Int. Dairy J. 17:641-647. http://dx.doi.org/10.1016/j. idairyj.2006.07.004.

Chobanian, A. V., G. L. Bakris, H. R. Black, W. C. Cushman, L. A. Green, J. L. Izzo, Jr., D. W. Jones, B. J. Materson, S. Oparil, J. T. Wright, Jr., E. J. Roccella, Joint National Committee on Prevention, Detection, Evaluation, and Treatment of High Blood Pressure, and National High Blood Pressure Education Pro- 
gram Coordinating Committee. 2003. The Seventh Report of the Joint National Committee on Prevention, Detection. Evaluation, and Treatment of High Blood Pressure (JNC 7). Hypertension 42:1206-1252.

Cruzado, M., C. Castro, N. Risler, and R. Miatello. 2002. Changes of inducible nitric oxide synthase in aortic cells during the development of hypertension: Effect of angiotensin II. Biocell 26:61-67.

Cushman, D. W., and H. Cheung. 1971. Spectrometric assay and properties of the angiotensin converting enzyme of rabbit lung. Biochem. Pharmacol. 20:1637-1648. http://dx.doi.org/10.1016/00062952(71)90292-9.

Daien, V., Y. Duny, J. Ribstein, G. Du Cailar, A. Mimran, M. Villain, J. P. Daures, and P. Fesler. 2012. Treatment of hypertension with renin-angiotensin system inhibitors and renal dysfunction: A systematic review and meta-analysis. Am. J. Hypertens. 25:126-132. http://dx.doi.org/10.1038/ajh.2011.180.

Donkor, O. N., A. Henriksson, T. K. Singh, T. Vasiljevic, and N. P. Shah. 2007. ACE-inhibitory activity of probiotic yogurt. Int. Dairy J. 17:1321-1331. http://dx.doi.org/10.1016/j.idairyj.2007.02.009.

Ebringer, L., M. Ferencik, and J. Krajcovic. 2008. Beneficial health effects of milk and fermented dairy products. Folia Microbiol. (Praha) 53:378-394. http://dx.doi.org/10.1007/s12223-008-0059-1 (Review)

European Food Safety Authority. 2011. Scientific Opinion on the substantiation of a health claim related to isoleucyl-prolyl-proline (IPP) and valyl-prolyl-proline (VPP) and maintenance of normal blood pressure pursuant to Article 13(5) of Regulation (EC) No 1924/2006. EFSA J. 9:2380.

Flambard, B., inventor. 2003. Peptides with anti-hypertensive properties. Hansen's Lab. B. Flambard, assignee. WO 2003/082019 A3.

Flambard, B., inventor. 2004a. Peptides with antihypertensive properties. Hansen's Lab. B. Flambard, assignee. WO 2004/015125 A1.

Flambard, B., inventor. 2004b. Peptides with heart rate reducer properties. Hansen's Lab. B. Flambard, assignee. WO 2004/089097 A1.

Flambard, B., and E. Johansen. 2007. Developing a functional dairy product: from research on Lactobacillus helveticus to industrial application of Cardi-04TM in novel antihypertensive drink yogurts. Pages:506-520 in Functional dairy products. Vol. 2. M. Saarela ed. CRC Press LLC, Boca Raton, FL.

González-Córdova, A. F., M. J. Torres-Llanez, J. C. RodríguezFigueroa, J. J. Espinoza-De-Los-Monteros, H. S. García, and B. Vallejo-Cordoba. 2011. Actividad inhibidora de la enzima convertidora de angiotensina en leches fermentadas con cepas de Lactobacillus. CYTA J. Food 9:146-151. http://dx.doi.org/10.1080/194 76337.2010 .499568 .

Gupta, S. K. 2011. Intention-to-treat concept: A review. Perspect. Clin. Res. 2:109-112.

Hata, Y., M. Yamamoto, M. Ohni, K. Nakajima, Y. Nakamura, and T. Takano. 1996. A placebo-controlled study of the effect of sour milk on blood pressure in hypertensive subjects. Am. J. Clin. Nutr. 64:767-771.

Hernández-Ledesma, B., M. Contreras, and I. Recio. 2011. Antihypertensive peptides: Production, bioavailability and incorporation to foods. Adv. Colloid Interface Sci. 165:23-35. http://dx.doi. org/10.1016/j.cis.2010.11.001.

Hirata, H., Y. Nakamura, H. Yada, S. Moriguchi, O. Kajimoto, and T. Takahashi. 2002. Clinical effects of new sour milk drink on mild or moderate hypertensive subjects. J. New. Rem. Clin. 51:61-69.

Jäkälä, P., and H. Vapaatalo. 2010. Antihypertensive peptides from milk proteins. Pharmaceuticals 3:251-272. http://dx.doi. org $/ 10.3390 /$ ph3010251.

Jauhiainen, T., M. Collin, M. Narva, T. Paussa, and R. Korpela. 2005a. Effect of long-term intake of milk peptides and minerals on blood pressure and arterial function in spontaneously hypertensive rats. Milchwissenschaft 60:358-362.

Jauhiainen, T., H. Vapaatalo, T. Poussa, S. Kyrönpalo, M. Rasmussen, and R. Korpela. 2005b. Lactobacillus helveticus fermented milk lowers blood pressure in hypertensive subjects in 24-h ambulatory blood pressure measurement. Am. J. Hypertens. 18:1600-1605. http://dx.doi.org/10.1016/j.amjhyper.2005.06.006.
Kajimoto, O., T. Kurosaki, J. Mizutani, N. Ikeda, K. Kaneko, K. Aihara, M. Yabune, and Y. Nakamura. 2002. Antihypertensive effects of liquid yogurts containing "lactotripeptides (VPP, IPP)" in mild hypertensive subjects. J. Nutr. Food 5:55-66

Khan, R. S., J. Grigor, R. Winger, and A. Win. 2013. Functional food product development-Opportunities and challenges for food manufacturers. Trends Food Sci. Technol. 30:27-37. http://dx.doi. org/10.1016/j.tifs.2012.11.004.

Kim, S., S. Park, and R. Choue. 2010. Effects of fermented milk peptides supplement on blood pressure and vascular function in spontaneously hypertensive rats. Food Sci. Biotechnol. 19:1409-1413. http://dx.doi.org/10.1007/s10068-010-0201-0

Korhonen, H., and A. Pihlanto. 2006. Bioactive peptides: Production and functionality. Int. Dairy J. 16:945-960. http://dx.doi. org/10.1016/j.idairyj.2005.10.012.

Majumder, K., and J. Wu. 2015. Molecular targets of antihypertensive peptides: Understanding the mechanisms of action based on the pathophysiology of hypertension. Int. J. Mol. Sci. 16:256-283.

Marques, C., M. Amorim, J. Odila, M. Estevez, D. Moura, C. Calhau, and H. Pinheiro. 2012. Bioactive peptides-Are there more antihypertensive mechanisms beyond ace inhibition? Curr. Pharm. Des. 18:4706-4713.

Masuda, O., Y. Nakamura, and T. Takano. 1996. Antihypertensive peptides are present in aorta after oral administration of sour milk containing these peptides to spontaneously hypertensive rats. J. Nutr. 126:3063-3068

Mizushima, S., K. Ohshige, J. Watanabe, M. Kimura, T. Kadowaki, and Y. Nakamura. 2004. Randomized controlled trial of sour milk on blood pressure in borderline hypertensive men. Am. J. Hypertens. 17:701-706.

Muguerza, B., M. Ramos, E. Sánchez, M. A. Manso, M. Miguel, A. Aleixandre, M. A. Delgado, and I. Recio. 2006. Antihypertensive activity of milk fermented by Enterococcus faecalis strains isolated from raw milk. Int. Dairy J. 16:61-69. http://dx.doi.org/10.1016/j. idairyj.2005.01.001.

Nakamura, Y.. O. Kajimoto, K. Kaneko, K. Aihara, J. Mizutani, N. Ikeda, A. Nishimura, and Y. Kajimoto. 2004. Effects of the liquid yogurts containing "lactotripeptide (VPP, IPP)" on high-normal blood pressure. J. Nutr. Food 7:123-137.

Nakamura, Y., O. Masuda, and T. Takano. 1996. Decrease of tissue angiotensin I-converting enzyme activity upon feeding sour milk in spontaneously hypertensive rats. Biosci. Biotechnol. Biochem. 60:488-489.

Nakamura, Y., N. Yamamoto, K. Sakai, A. Okubo, A. Yamazaki, and T. Takano. 1995a. Purification and characterization of angiotensin I-converting enzyme inhibitors form sour milk. J. Dairy Sci. 78:777-783.

Nakamura, Y., N. Yamamoto, K. Sakai, and T. Takano. 1995b. Antihypertensive effect of sour milk and peptides isolated from it that are inhibitors to angiotensin I-converting enzyme. J. Dairy Sci. 78:1253-1257.

Nurminen, M. L., M. Sipola, H. Kaarto, A. Pihlanto-Leppala, K. Piilola, R. Korpela, O. Tossavainen, H. Korhonen, and H. Vapaatalo. 2000. Alphalactorphin lowers blood pressure measured by radiotelemetry in normotensive and spontaneously hypertensive rats. Life Sci. $66: 1535-1543$.

Phelan, M., and D. Kerins. 2011. The potential role of milk-derived peptides in cardiovascular disease. Food Funct. 2:153-167. http:// dx.doi.org/10.1039/c1fo10017c.

Pihlanto, A., and H. Korhonen. 2003. Bioactive peptides and proteins. Adv. Food Nutr. Res. 47:175-276. http://dx.doi.org/10.1016/ S1043-4526(03)47004-6.

Pihlanto, A., T. Virtanen, and H. Korhonen. 2010. Angiotensin I converting enzyme (ACE) inhibitory activity and antihypertensive effect of fermented milk. Int. Dairy J. 10:3-10. http://dx.doi. org/10.1016/j.idairyj.2009.07.003.

Quiros, A., M. Ramos, B. Muguerza, M. Delgado, M. Miguel, A. Aleixandre, and I. Recio. 2007. Identification of novel antihypertensive peptides in milk fermented with Enterococcus faecalis. Int. Dairy J. 17:33-41. http://dx.doi.org/10.1016/j.idairyj.2005.12.011. 
Ricci-Cabello, I., M. Olalla, and R. Artacho. 2012. Possible role of milk-derived bioactive peptides in the treatment and prevention of metabolic syndrome. Nutr. Rev. 70:241-255. http://dx.doi. org/10.1111/j.1753-4887.2011.00448.x.

Rodríguez-Figueroa, J. C., A. F. González-Córdova, H. AstiazaránGacía, and B. Vallejo-Córdoba. 2013b. Hypotensive and heart rate-lowering effects in rats receiving milk fermented by specific Lactococcus lactis strains. Br. J. Nutr. 109:827-833. http://dx.doi. org/10.1017/S0007114512002115.

Rodríguez-Figueroa, J. C., A. F. González-Córdova, H. AstiazaránGarcía, A. Hernández-Mendoza, and B. Vallejo-Córdoba. 2013a. Antihypertensive and hypolipidemic effect of milk fermented by specific Lactococcus lactis strains. J. Dairy Sci. 96:4094-4099. http://dx.doi.org/10.3168/jds.2012-6014.

Rodríguez-Figueroa, J. C., A. F. González-Córdova, M. J. TorresLlanez, H. S. García, and B. Vallejo-Córdoba. 2012. Novel angiotensin I-converting enzyme inhibitory peptides produced in fermented milk by specific wild Lactococcus lactis strains. J. Dairy Sci. 95:5536-5543. http://dx.doi.org/10.3168/jds.2011-5186.

Rodríguez-Figueroa, J. C., R. Reyes-Díaz, A. F. González-Córdova, R. Troncoso-Rojas, I. Vargas-Arispuro, and B. Vallejo-Córdoba. 2010. Angiotensin-converting enzyme inhibitory activity of milk fermented by wild and industrial Lactococcus lactis strains. J. Dairy Sci. 93:5032-5038. http://dx.doi.org/10.3168/jds.2010-3103.

Seppo, L., T. Jauhiainen, T. Poussa, and R. Korpela. 2003. A fermented milk high in bioactive peptides has a blood pressure-lowering effect in hypertensive subjects. Am. J. Clin. Nutr. 77:326-330.

Seppo, L., O. Kerojoki, T. Suomalainen, and R. Korpela. 2002. The effect of a Lactobacillus helveticus LBK-16H fermented milk on hypertension-A pilot study on humans. Milchwissenschaft 57:124127.

Sipola, M., P. Finckenberg, R. Korpela, H. Vapaatalo, and M. Nurminen. 2002. Effect of long-term intake of milk products on blood pressure in hypertensive rats. J. Dairy Res. 69:103-111.
Sipola, M., P. Finckenberg, J. Santisteban, R. Korpela, H. Vapaatalo, and M. Nurminen. 2001. Long term intake of milk peptides attenuates development of hypertension in spontaneously hypertensive rats. J. Physiol. Pharmacol. 52:745-754.

Torres-Llanez, M. J., B. Vallejo-Cordoba, and A. F. González-Córdova. 2005. Péptidos bioactivos derivados de las proteínas de la leche. Arch. Latinoam. Nutr. 55:111-117.

Turpeinen, A. M., S. Jarvenpaa, H. Kautiainen, R. Korpela, and H. Vapaatalo. 2013. Antihypertensive effects of bioactive tripeptidesa random effects meta-analysis. Ann. Med. 45:51-56. http:// dx.doi.org/10.3109/07853890.2012.663926.

Udenigwe, C. 2014. Bioinformatics approaches, prospects and challenges of food bioactive peptide research. Trends Food Sci. Technol. 36:137-143. http://dx.doi.org/10.1016/j.tifs.2014.02.004.

Udenigwe, C., and A. Mohan. 2014. Mechanisms of food protein-derived antihypertensive peptides other than ACE inhibition. J. Funct. Foods 8C:45-52. http://dx.doi.org/10.1016/j.jff.2014.03.002.

Vallejo Galland, B., A. F. González Córdoba, and J. C. Rodríguez Figueroa, inventors. 2014. Lactococcus lactis strains and bacterial preparations thereof, for the production of bioactive peptides having anti-hypertensive and cholesterol-lowering effects in mammals, nutritional and therapeutic products produced therefrom. Centro de Investigacion en Alimentacion. A. C. Desarrollo. B. Vallejo, and A. Gonzalez, assignee. US Pat. No. 8,865,155.

Vermeirssen, V., J. Van Camp, and W. Verstraete. 2004. Bioavailability of angiotensin I converting enzyme inhibitory peptides. Br. J. Nutr. 92:357-366.

WHO. 2011. Enfermedades cardiovasculares. World Health Organization. Accessed Apr. 12, 2012. http://www.who.int/mediacentre/ factsheets/fs317/es/index.html.

Yamamoto, N., A. Akino, and T. Takano. 1994. Antihypertensive effects of different kinds of fermented milk in spontaneously hypertensive rats. Biosci. Biotechnol. Biochem. 58:776-778. http:// dx.doi.org/10.1271/bbb.58.776. 